\author{
B. Belan ${ }^{1}$, M. Dzevenko ${ }^{1}$, M. Daszkiewicz ${ }^{2}$, R. Gladyshevskii ${ }^{1}$
}

\title{
Interaction of Components in the Lu-Ag-Si System at $500{ }^{\circ} \mathrm{C}$
}

\author{
${ }^{1}$ Ivan Franko National University of Lviv, Lviv, Ukraine, mariya.dzevenko@lnu.edu.ua \\ ${ }_{2}^{2}$ Institute of Low Temperature and Structure Research, Polish Academy of Sciences, Wroctaw 2, Poland, \\ m.daszkiewicz@int.pan.wroc.pl
}

\begin{abstract}
Isothermal section of the $\mathrm{Lu}-\mathrm{Ag}-\mathrm{Si}$ system at $500{ }^{\circ} \mathrm{C}$ was studied by means of $\mathrm{X}$-ray powder diffraction, microstructure and EDX-analyses in the whole concentration range. The existence of earlier reported binary compounds $\mathrm{LuAg}_{4}, \mathrm{LuAg}_{2}, \mathrm{LuAg}$ and $\mathrm{LuSi}_{2}, \mathrm{LuSi}_{1} \mathrm{Lu}_{5} \mathrm{Si}_{3}, \mathrm{Lu}_{5} \mathrm{Si}_{4}$ was confirmed. New binary compound $\mathrm{Lu}_{3} \mathrm{Si}_{5}$ (own str. type) was found. Almost none of the binary silicides dissolve more than 5 at.\% of third component. The exception is the existence of the substitution type solid solutions based on $\mathrm{LuAg}_{2}$ ( $\mathrm{MoSi}_{2}$-type structure), which dissolves up to 20 at.\% $\mathrm{Si}$, as well as on $\mathrm{Lu}_{5} \mathrm{Si}_{3}$ ( $\mathrm{Mn}_{5} \mathrm{Si}_{3}$-type structure), which dissolves up to 15 at.\% $\mathrm{Ag}$. The crystal structure of the LuSi compound was redetermined by X-ray single crystal diffraction (TII-type, space group Cmcm, $\mathrm{a}=4.1493(3), \mathrm{b}=10.2641(7), \mathrm{c}=3.7518(2) \AA, \mathrm{R}=0.0173 \mathrm{wR}=0.0415$ for 173 independent reflections). No ternary compound is observed in the $\mathrm{Lu}-\mathrm{Ag}$-Si system.
\end{abstract}

Keywords: ternary system; isothermal section; crystal structure.

Received 11 January 2021; Accepted 15 February 2021.

\section{Introduction}

Ternary systems consisting of rare earth metals, silver and silicon attract particular interest, because of phases with physical properties interesting for various fields of science and technology. Most of such systems were studied in some detail. The isothermal sections of the phase diagrams have been constructed for the following systems: $\mathrm{La}-\mathrm{Ag}-\mathrm{Si}$ at $500{ }^{\circ} \mathrm{C}$ (2 compounds) [1]; $\mathrm{Ce}-\mathrm{Ag}-\mathrm{Si}$ at $850{ }^{\circ} \mathrm{C}\left(3\right.$ compounds) ant at $500^{\circ} \mathrm{C}(3$ compounds) [2, 3]; $\mathrm{Pr}-\mathrm{Ag}-\mathrm{Si}$ at $800{ }^{\circ} \mathrm{C}$ (2 compounds) and at $500{ }^{\circ} \mathrm{C}$ (3 compounds) $[4,5] ; \mathrm{Nd}-\mathrm{Ag}-\mathrm{Si}$ at $600{ }^{\circ} \mathrm{C}$ (4 compounds) [6]; $\mathrm{Eu}-\mathrm{Ag}-\mathrm{Si}$ at $400{ }^{\circ} \mathrm{C}$ (2 compounds) [3]; Y-Ag-Si at $600{ }^{\circ} \mathrm{C}$ (5 compounds) $[4,5]$. Hence, all these systems were characterized by formation of small number of ternary compounds. The rest $R$-Ag-Si ( $\mathrm{R}=$ $\mathrm{Sm}, \mathrm{Gd}, \mathrm{Tb}-\mathrm{Lu}$ ) systems were studied identifying only isostructural compounds. Thus, one ternary silicide has been found in each system with $\mathrm{Ho}, \mathrm{Tm}, \mathrm{Lu}$ and five silicides have been found in the system with Y [7].

The aim of the present work is the investigation of component interaction and construction of the isothermal section of the Lu-Ag-Si phase diagram at $500{ }^{\circ} \mathrm{C}$. This work is a part of our systematic investigations of three component intermetallics based on the silicon with rare earth and transition metals. So far, the Lu-Ag-Si system have been not investigated in the full concentration range and only the existence of LuAgSi compound (ZrNiAltype, space group $P-62 m$, Pearson symbol $h P 9$; $a=6.923(2), c=4.110(3) \AA$ ) [8]) has been found.

The binary systems Lu-Ag, Ag-Si and Lu-Si, which are boundary ones around the investigated ternary system, were not fully investigated [9]. The crystal data for already reported compounds were collected in Table 1. The phase diagrams in the full temperatureconcentration interval was constructed only for the Ag-Si system. No binary compounds were formed in this system except the metastable phase $\mathrm{Ag}_{2} \mathrm{Si}$ [10]. The phase diagram of the Lu-Ag system was constructed only in the region with a small content of lutetium [9]. The formation of three binary compounds i.e. $\mathrm{LuAg}, \mathrm{LuAg}_{2}$ and $\mathrm{LuAg}_{4}$ were observed in this system. The system LuSi was also partly investigated. According to Ref. [9], five binary compounds $\mathrm{Lu}_{5} \mathrm{Si}_{3}, \mathrm{LuSi}, \mathrm{LuSi}_{2}, \mathrm{LuSi}_{3}$ and $\mathrm{Lu}_{5} \mathrm{Si}_{4}$ can be obtained in this system. Here, we present the crystal structure of the simplest compound LuSi. 
Crystallographic characteristics of binary compounds of the $\mathrm{Lu}-\mathrm{Ag}-\mathrm{Si}$ system

\begin{tabular}{|c|c|c|c|c|c|c|c|}
\hline \multirow{2}{*}{ Compound } & \multirow{2}{*}{$\begin{array}{c}\text { Structure } \\
\text { type }\end{array}$} & \multirow{2}{*}{$\begin{array}{l}\text { Pearson } \\
\text { symbol }\end{array}$} & \multirow{2}{*}{ Space group } & \multicolumn{3}{|c|}{ Lattice parameters, $\AA$} & \multirow{2}{*}{ Ref. } \\
\hline & & & & $a$ & $b$ & $c$ & \\
\hline $\mathrm{Lu}_{5} \mathrm{Si}_{3}$ & $\mathrm{Mn}_{5} \mathrm{Si}_{3}$ & hP16 & $P 6_{3} / \mathrm{mcm}$ & 8.24 & - & 6.13 & [15] \\
\hline \multirow{2}{*}{$\mathrm{Lu}_{5} \mathrm{Si}_{4}$} & - & & $P 2_{1} / c$ & 14.11 & 7.46 & 7.20 & [16] \\
\hline & & & & & $\beta=92.1^{\circ}$ & & \\
\hline \multirow[t]{2}{*}{$\mathrm{LuSi}$} & TII & oS8 & $\mathrm{Cmcm}$ & 4.15 & 10.124 & 3.75 & [17] \\
\hline & & & & $4.1493(3)$ & $10.2641(7)$ & $3.7518(2)$ & [18] \\
\hline $\mathrm{LuSi}_{2}$ & $\mathrm{AlB}_{2}$ & $h P 3$ & $P 6 / \mathrm{mmm}$ & 3.745 & - & 4.050 & {$[19,20,21]$} \\
\hline $\mathrm{Lu}_{3} \mathrm{Si}_{5}$ & $\mathrm{Lu}_{3} \mathrm{Si}_{5}$ & $h P 54$ & $P 6_{2} 22$ & $6.4815(4)$ & - & $24.241(3)$ & [14] \\
\hline $\mathrm{LuSi}_{3} *$ & $\mathrm{YbSi}_{3}$ & $t 132$ & $I 4 / \mathrm{mmm}$ & 7.1835 & - & 10.471 & [22] \\
\hline $\mathrm{LuAg}_{4}$ & $\mathrm{MoNi}_{4}$ & $t I 10$ & $I 4 / m$ & 6.6696 & - & 4.1581 & [23] \\
\hline $\mathrm{LuAg}_{2}$ & $\mathrm{MoSi}_{2}$ & $t 16$ & $14 / \mathrm{mmm}$ & 3.628 & - & 9.113 & [24] \\
\hline LuAg & $\mathrm{CsCl}$ & $c P 2$ & $P m 3 m$ & 3.536 & - & - & [25] \\
\hline $\mathrm{Ag}_{2} \mathrm{Si} * *$ & $\mathrm{URe}_{2}$ & $o S 24$ & Cmcm & 5.560 & 9.160 & 8.490 & [26] \\
\hline
\end{tabular}

* high temperature/high pressure phase (it was not found under the condition of experiment)

** metastable phase

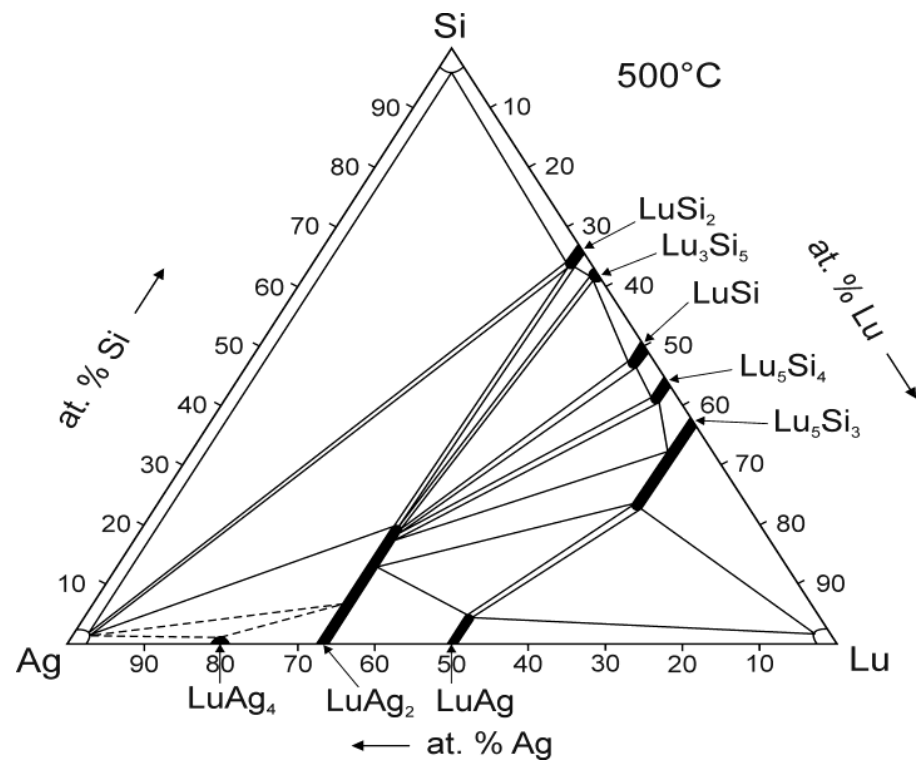

Fig. 1. The isothermal section of the $\mathrm{Lu}-\mathrm{Ag}-\mathrm{Si}$ system at $500{ }^{\circ} \mathrm{C}$.

\section{Materials and methods}

Starting materials for the preparation of the alloys were ingots of the lutetium, silver, and silicon, each of purity higher than $99.9 \mathrm{wt} \%$. 60 binary and ternary samples were synthesized in an arc-furnace on a watercooled $\mathrm{Cu}$-plate under an argon atmosphere (sponge $\mathrm{Ti}$ was used as a getter). The buttons were turned over and remelted two times to ensure homogeneity. The weight losses were smaller than $2 \%$ in all cases. The alloys were subsequently sealed in evacuated silica tubes, annealed at $500^{\circ} \mathrm{C}$ during one month and quenched in cold water without breaking the tubes.

Investigation of the isothermal section of the $\mathrm{Lu}-\mathrm{Ag}$ Si system was performed by X-ray powder diffraction. The X-ray phase analysis was performed using film data (Debye-Scherrer technique, RKD-57.3 camera, $\mathrm{Cr} K$ radiation) and powder diffractometers (DRON-2.0, Fe $K_{\alpha}$ radiation; HZG-4A, $\mathrm{Cu} K_{\alpha}$ radiation). The indexing of the obtained diffraction data of the ternary alloys was performed by comparison with calculated data. The lattice parameters of some phases were calculated using the program [11]. The microstructure of some samples was studied visually on polished and etched surfaces, by using a microscope "NEOPHOT 30" in reflected light.

Single crystal X-ray diffraction was performed at room temperature with graphite-monochromatized Mo $K_{\alpha}$ radiation $(\lambda=0.71073 \AA)$ on an Oxford Diffraction Xcalibur four-circle diffractometer equipped with a CCD detector and it confirmed the tetragonal lattice. Data collection and reduction were made using CRYSALIS CCD and CRYSALIS RED programs [12] taking into account a numerical absorption correction. The structure was solved by Direct Methods, and refined using the SHELXL-2018/3 program package [13].

\section{Results and discussion}

The isothermal section of the $\mathrm{Lu}-\mathrm{Ag}-\mathrm{Si}$ ternary system was established at $500{ }^{\circ} \mathrm{C}$ for the whole concentration range, by means of X-ray powder diffraction, partly optical microscopy and EDX analyses (Fig. 1). The crystallographic parameters of all phases 


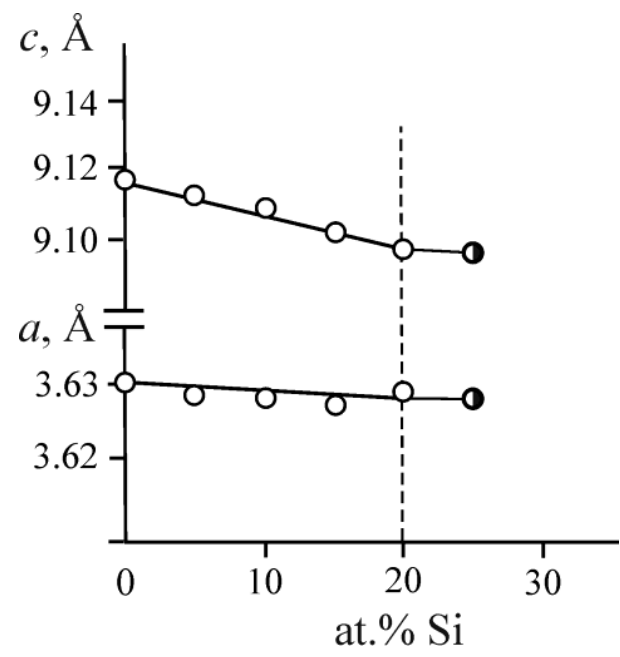

a)

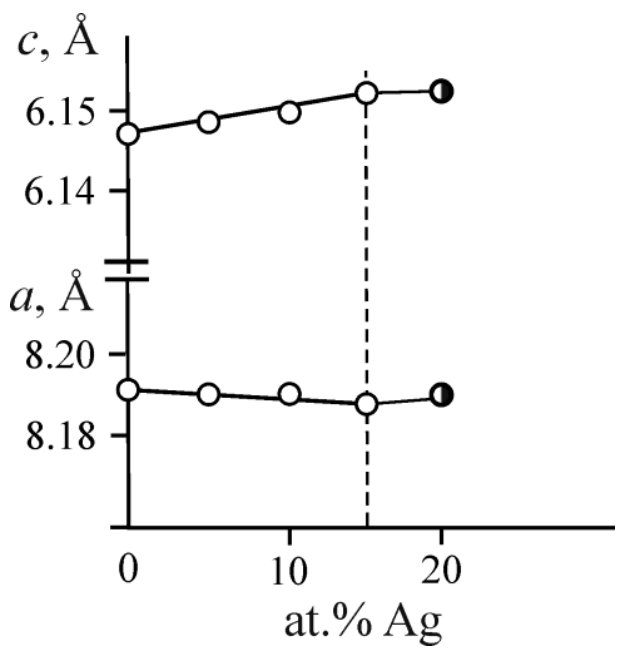

b)

Fig. 2. Dependence of the lattice parameters of solid solution based on a) $\mathrm{LuAg}_{2}$ vs. the at.\% $\mathrm{Si}$ and b) $\mathrm{Lu}_{5} \mathrm{Si}_{3}$ vs. the at.\% Ag.

existing in the investigated system are given in Table 1. It was confirmed that the following binary compounds exist at $870 \mathrm{~K}: \mathrm{LuAg}_{4}, \mathrm{LuAg}_{2}, \mathrm{LuAg} ; \mathrm{LuSi}_{2}, \mathrm{LuSi}$, $\mathrm{Lu}_{5} \mathrm{Si}_{3}, \mathrm{Lu}_{5} \mathrm{Si}_{4}$. Apart from these, a new binary compound $\mathrm{Lu}_{3} \mathrm{Si}_{5}$ was found, which crystallizes in its own structure type, space group $P 6_{2} 22, a=6.4815$ (4), $c=24.241$ (3) $\AA$ [14]. More detailed information about this binary silicide can be found in a separate future publication.

The solid solution based on $\operatorname{LuAg}_{2}$ ( $\mathrm{MoSi}_{2}$-type) binary compound and $\mathrm{Lu}_{5} \mathrm{Si}_{3}\left(\mathrm{Mn}_{5} \mathrm{Si}_{3}\right.$-type $)$ across the sections of lutetium exists in this system. The homogeneity regions of these solid solutions were revealed from the variations of lattice parameters (Fig. 2a). Such variations of lattice parameters take place due to the substitution of the larger $\mathrm{Ag}$ atoms $(r=1.444 \AA)$ by the smaller Si atoms $(r=1.28 \AA)$ [27] or vice versa. Therefore, the homogeneity region of $\mathrm{LuAg}_{2}$ based solid solution extends up to 20.0 at. $\% \mathrm{Si}$, and homogeneity region of $\mathrm{Lu}_{5} \mathrm{Si}_{3}$ based solid solution extends up to 15.0 at.\% $\mathrm{Ag}$ (Fig. 2b). The rest binary compounds do not dissolve more than $\sim 5$ at. $\%$ of third component.

The ternary compounds are not formed in $\mathrm{Lu}-\mathrm{Ag}-\mathrm{Si}$ system under the experimental conditions used. The existence of earlier reported compound LuAgSi of the ZrNiAl-type structure [8] was not confirmed at the annealing temperature of $500{ }^{\circ} \mathrm{C}$.

The phase equilibria in the $\mathrm{Lu}-\mathrm{Ag}-\mathrm{Si}$ system at $500{ }^{\circ} \mathrm{C}$ was verified by microstructural analysis of some alloys. The microstructural analysis of $\mathrm{Lu}_{20} \mathrm{Ag}_{60} \mathrm{Si}_{20}$, $\mathrm{Lu}_{20} \mathrm{Ag}_{55} \mathrm{Si}_{25}$ and $\mathrm{Lu}_{20} \mathrm{Ag}_{30} \mathrm{Si}_{50}$ samples revealed the existence of the three-phase region formed by $\mathrm{Ag}, \mathrm{Si}$ and binary phase $\mathrm{Lu}_{3} \mathrm{Si}_{5}$. The equilibrium between the solid solutions based on the $\mathrm{LuAg}_{2}$ and $\mathrm{Lu}_{3} \mathrm{Si}_{5}$ compounds was confirmed by the microstructural analysis of two-phase samples $\mathrm{Lu}_{37} \mathrm{Ag}_{10} \mathrm{Si}_{53}$ and $\mathrm{Lu}_{37} \mathrm{Ag}_{5} \mathrm{Si}_{58}$. The $\mathrm{Lu}_{62.5} \mathrm{Ag}_{25} \mathrm{Si}_{12.5}, \mathrm{Lu}_{62.5} \mathrm{Ag}_{20} \mathrm{Si}_{17.5}$ sample consist of binary compound $\mathrm{LuAg}$, $\mathrm{Lu}$ and solid solution basing on $\mathrm{Lu}_{5} \mathrm{Si}_{3}$, thereby showing existence of respective three-phase region.
Additionally, the crystal structure of binary compound LuSi was reinvestigated by means of X-ray single crystal method, because earlier data concerned only the structure type and lattice parameters of this compound. The crystal data and refinement details of this compound are listed in Table 2. The reasonable values of the residual factors of the structure reliability confirmed that this compound adopt TlI-type structure. The coordination and anisotropic displacement parameters of atoms are presented in Table 3. Binary silicides of equiatomic composition exist in all the systems with rare-earth metals and silicon [9] and adopt two related structure types. The binary silicides with $\mathrm{La}, \mathrm{Ce}, \mathrm{Pr}, \mathrm{Nd}$, $\mathrm{Sm}, \mathrm{Gd}$, and Tb crystallize in the FeB-type. The silicides with $\mathrm{Eu}, \mathrm{Tm}, \mathrm{Yb}$, and Lu adopt the TII-type, whereas the Dy, Ho, and Er bearing compounds crystallize in both these structure types (Fig. 3).

The interaction of elements of the yttrium subgroup, which includes lutetium, with silver and silicon has been studied only for Y. Generally, the Y-Ag-Si system differs significantly from the investigated $\mathrm{Lu}-\mathrm{Ag}-\mathrm{Si}$ system. In the system with $\mathrm{Y}$, no significant solubility of the third component in the binary compounds was observed. The five ternary compounds, namely $\mathrm{YAg}_{2} \mathrm{Si}_{2} \quad\left(\mathrm{CeAl}_{2} \mathrm{Ga}_{2}-\right.$ type), $\mathrm{YAg}_{1.4-1.0} \mathrm{Si}_{0.6-1.0}\left(\mathrm{Fe}_{2} \mathrm{P} / \mathrm{ZrNiAl-type}\right), \mathrm{YAg}_{0.7} \mathrm{Si}_{1.3}$ (AlB 2 -type), $\quad \mathrm{YAg}_{0.6} \mathrm{Si}_{1.4} \quad\left(\alpha\right.$-ThSi $\mathrm{T}_{2}$-type $) \quad$ and $\left.\mathrm{YAg}_{0.4-0.2} \mathrm{Si}_{1.6-1.8}\right) \quad\left(\alpha-\mathrm{ThSi}_{2}\right.$-type exist in the $\mathrm{Y}-\mathrm{Ag}-\mathrm{Si}$ system at $600{ }^{\circ} \mathrm{C}[4,5]$.

Comparing the Lu-Ag-Si system with familiar ternary systems of other rare earth metals, it should be mentioned that the investigated system is not very similar to the other one. No ternary compounds have been found at the annealing temperature in $\mathrm{Lu}-\mathrm{Ag}-\mathrm{Si}$ system, whereas two and more ternary silicides have been found in related systems. Particularly, the number of ternary compounds with different structure types $\left(\mathrm{AlB}_{2}, \alpha-\mathrm{ThSi}_{2}\right.$, $\mathrm{LaPtSi}, \mathrm{LiGaGe}$ and $\mathrm{ZrNiAl}$ ) form across the section 33.3 at. $\% R E$ in the $R E-\mathrm{Ag}-\mathrm{Si}$ systems $(R E=\mathrm{Ce}, \mathrm{Pr}, \mathrm{Nd}$, $\mathrm{Eu}, \mathrm{Y})$. It is interesting that the stoichiometric ternary compound exists in the Y-Ag-Si system and is not 
Table 2

Crystallographic data and experimental details for the LuSi compound

\begin{tabular}{|l|l|}
\hline Refined composition & LuSi \\
\hline Structure type & TII \\
\hline Pearson code & $o S 8$ \\
\hline Space group, $Z$ & $C m c m, 4$ \\
\hline Unit cell parameters, $\AA$ & $a=4.1493(3), b=10.2641(7), c=3.7518(2)$ \\
\hline Cell volume, $\AA^{3}$ & $V=159.784(18)$ \\
\hline Calculated density, g/cm ${ }^{3}$ & 8.44 \\
\hline Absorption coefficient, $\mathrm{mm}^{-1}$ & 61.86 \\
\hline F(000) & 340 \\
\hline$\theta$ range for data collection & $4.0-32.2$ \\
\hline Limiting indices & $-6 \leq h \leq 5,-14 \leq k \leq 14,-5 \leq l \leq 5$ \\
\hline Reflections collected & 1037 \\
\hline Independent reflections / $R_{\text {int }}$ & $174 / 0.0307$ \\
\hline Reflections with $I>2 \sigma(I)$ & 173 \\
\hline Refinement method & Full-matrix least-square on $F^{2}$ \\
\hline Data / ref. parameters & $174 / 10$ \\
\hline Goodness-of-fit on $F^{2}$ & 1.206 \\
\hline Final indices $R 1 / w R 2[I>2 \sigma(I)]$ & $0.0186 / 0.0415$ \\
\hline Final indices $R 1 / w R 2($ all data $)$ & $0.0186 / 0.0415$ \\
\hline Largest diff. peak / hole, e $\AA^{-3}$ & 1.61 and -3.48 \\
\hline
\end{tabular}

Table 3

Atomic coordinates and thermal displacement parameters for $\mathrm{LuSi}^{\mathrm{a}}$

\begin{tabular}{|c|c|c|c|c|c|c|}
\hline Atom & WS & Occupation & $x$ & $y$ & $z$ & $U_{\text {iso }}$ \\
\hline $\mathrm{Lu}$ & $4 c$ & 1 & $1 / 2$ & $0.14108(4)$ & $1 / 4$ & $0.0061(2)$ \\
\hline $\mathrm{Si}$ & $4 c$ & 1 & $1 / 2$ & $0.4210(3)$ & $1 / 4$ & $0.0066(5)$ \\
\hline Atom & $U_{11}$ & $U_{22}$ & $U_{33}$ & $U_{23}$ & $U_{13}$ & $U_{12}$ \\
\hline $\mathrm{Lu}$ & $0.0053(3)$ & $0.0067(3)$ & $0.0062(3)$ & 0 & 0 & 0 \\
\hline Si1 & $0.0053(11)$ & $0.0083(11)$ & $0.0062(10)$ & 0 & 0 & 0 \\
\hline
\end{tabular}

${ }^{\text {a }} U_{\text {iso }}$ is defined as one third of the trace of the orthogonalized $U_{\mathrm{ij}}$ tensor. The anisotropic displacement factor exponent takes the form: $-2 \pi^{2}\left(U_{11} h^{2} a^{* 2}+U_{22} k^{2} b^{* 2}+U_{33} l^{2} c^{* 2}+2 U_{12} h k a^{*} b^{*}+2 U_{13} h l a^{*} c^{*}+2 U_{23} k l b^{*} c^{*}\right)$.

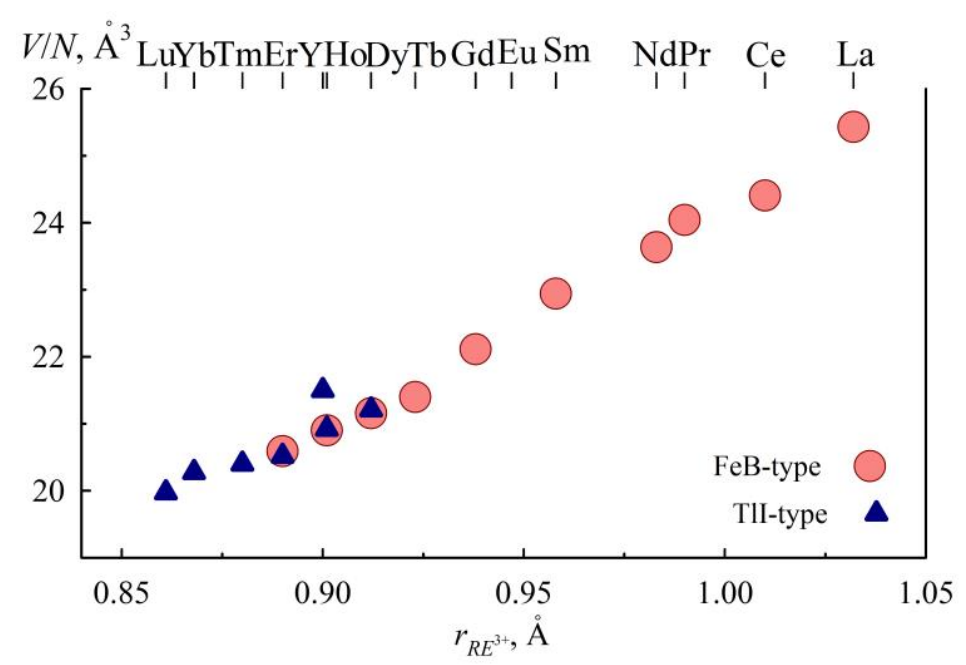

Fig. 3. Dependence of the parameter $V / N$ on the $R E^{3+}$ radius in $R E S i$ compounds.

formed in the Lu-Ag-Si one at the condition of experiment. Besides, in the investigated systems with metals of the cerium subgroup, compounds with $\mathrm{CeAl}_{2} \mathrm{Ga}_{2}$ type structure are formed on the section 20 at.\% rare earth metals. The similar feature of all systems is formation of solid solutions based on the same binary compounds, in the homogeneity ranges of which $\mathrm{Ag} / \mathrm{Si}$ or $\mathrm{Si} / \mathrm{Ag}$ substitutions take place. It should be noted that the length of solid solutions based on binary compounds $R E \mathrm{Ag}_{2}$ is directly dependent on the ordinal 
number of the rare earth: in the transition from La [1] to Lu solubility increases from 5 to 20 at. $\% \mathrm{Si}$.

\section{Conclusion}

The phase equilibria of $\mathrm{Lu}-\mathrm{Ag}-\mathrm{Si}$ system at $500{ }^{\circ} \mathrm{C}$ are characterized by the formation of the substitution solid solutions based on $\mathrm{LuAg}_{2}$ ( $\mathrm{MoSi}_{2}$-type structure), which dissolves up to 20 at. $\% \mathrm{Si}$, and on $\mathrm{Lu}_{5} \mathrm{Si}_{3}\left(\mathrm{Mn}_{5} \mathrm{Si}_{3}-\right.$ type structure), which dissolves up to 15 at.\% $\mathrm{Ag}$. No ternary compounds exist in investigated system. Additionally, the detailed crystal structure investigation was performed for binary LuSi (TII-type) compound.

Belan B.D. - PhD (in Chemical Sciences), Senior Researcher, Leading Researcher;

Dzevenko M.V. - PhD (in Chemical Sciences), Research Fellow;

Daszkiewicz M. - Dr. Hab., Engineer;

Gladyshevskii R.E. - Professor, Corresponding Member of the NAS of Ukraine, DSc (in Chemical Sciences), Director of the Department of Inorganic Chemistry, Vice-Rectorfor Science and Research.

[1] O. Bardyn, B. Belan, O. Bodak, O. Protsyk, Z. Shpyrka, Visnyk Lviv Univ. Ser. Chem. 40, 57 (2001).

[2] E. Cordruwisch, D. Kaczorowski, P. Rogl, A. Saccjne, R. Ferro, J. Alloys Compd. 320(2), 308 (2001) (https://doi.org/10.1016/S0925-8388(00)01474-2).

[3] B. Belan, O. Bodak, R. Gladyshevskii, I. Soroka, B. Kuzhel, O. Protsyk, I. Stets, J. Alloys Compd. 396,212 (2005) (https://doi.org/10.1016/j.jallcom.2004.12.035).

[4] I.A. Savisyuk, Phases, crystal structures and electrical properties of compounds in systems $\{\mathrm{Y}, \mathrm{Pr}\}-\mathrm{Ag}-\{\mathrm{Si}$, $\mathrm{Ge}, \mathrm{Sn}\}$, Abstract of the thesis for candidate degree (Lviv, 2000).

[5] I. Savysyuk, O. Shcherban, N. Semuso, R. Gladyshevskii, E. Gladyshevskii, Chem. Met. Alloys. 5, 103 (2012).

[6] O.V. Zaplatunsky, Yu.M. Prots, P.S. Salamakha, L.O. Muratova, O. Bodak, J. Alloys Compd. 232, Ll (1996) (https://doi.org/10.1016/0925-8388(95)01928-6).

[7] P. Villars, K. Cenzual, R. Gladyshevskii, Handbook of Inorganic Substances (Walter de Gruyter, Berlin, 2017).

[8] A. Iandelli, J. Less-Common Met. 113, L25 (1985) (https://doi.org/10.1016/0022-5088(85)90295-4).

[9] P. Villars, K. Cenzual (Eds.), Pearson's Crystal Data - Crystal Structure Database for Inorganic Compounds, Release 2017/18 (ASM International, Materials Park, Ohio, USA, 2017).

[10] R.W. Olesinski, A.B. Gokhale, G.J. Abbaschian, Bulletin of Alloy Phase Diagrams. 10, 635 (1989).

[11] D.B. Wiles, A. Sakthivel, R.A. Young,Program DBW3.2s for Rietveld Analysis of X-ray and Neutron Powder Diffraction Patterns. Version 9411.PC. (Atlanta, Georgia Institute of Thechnology, 1995).

[12] Rigaku Oxford Diffraction, CrysAlisPro Software System, Version 1.171 (Rigaku Corporation, Oxford, UK, 2015).

[13] G.M. Sheldrick, Acta Crystallogr. C 71, 3 (2015) (https://doi.org/10.1107/S2053229614024218).

[14] B. Belan, M. Manyako, R. Gladyshevskii, R. Černý, XIV International Conference on Crystal Chemistry of Intermetallic Compounds (Lviv, 2019), p. 124.

[15] I. Mayer, I. Shidlovsky, Inorg. Chem. 8, 1240 (1969) (https://doi.org/10.1021/ic50076a008).

[16] G.S. Smith, A.G. Tharp, Q.C. Johnson, Acta Crystallogr. 22, 940

(1967) (https://doi.org/10.1107/S0365110X67001902).

[17] E.I. Gladyshevskii, P.I. Krypyakevych, J. Struct. Chem. 5, 789 (1964) (https://doi.org/10.1007/BF00744231).

[18] B. Belan, M. Manyako, M. Dzevenko, M. Daszkiewicz, R. Gladyshevskii, XXII International Online Seminar on Physics and Chemistry of Solids (Lviv, 2020), p. 47.

[19] E.I. Gladyshevskii, Dopov. Akad. Nauk Ukr. RSR. 886 (1963) (in Ukrainian).

[20] A. Iandelli, A. Palenzona, G.L. Olcese, J. Less-Common Met. 64, 213 (1979) (https://doi.org/10.1016/00225088(79)90172-3).

[21] I.P. Mayer, E. Banks, B. Post, J. Phys. Chem. 66, 693 (1962) (https://doi.org/10.1021/j100810a028).

[22] U. Schwarz, A. Wosylus, H. Rosner, W. Schnelle, A. Ormeci, K. Meier, A.I. Baranov, M. Nicklas, S. Leipe, C.J. Müller, Y. Grin, J. Am. Chem. Soc. 134, 13558 (2012) (https://doi.org/10.1021/ja3055194).

[23] O.D. McMasters, K.A. Gschneidner Jr., R.F. Venteicher, Acta Crystallogr. B. 26, 1224 (1970) (https://doi.org/10.1107/S0567740870003928).

[24] A.E. Dwight, J.W. Downey, R.A. Conner Jr., Acta Crystallogr. 22, $745 \quad$ (1967) (https://doi.org/10.1107/S0365110X6700146X).

[25] C.C. Chao, H.L. Luo, P. Duwez, J. Appl. Phys. 34(7), (1971) (https://doi.org/10.1063/1.1729720).

[26] C. Suryanarayana, J. Less-Common Met. 35, 347 (1974) (https://doi.org/10.1016/0022-5088(74)90248-3).

[27] J. Emsley The Elements, 3-th edition (Oxford University Press, Oxford, 1998). 


\section{Б. Белан ${ }^{1}$, М. Дзевенко ${ }^{1}$, М. Дашкевич ${ }^{2}$, Р. Гладишевський ${ }^{1}$}

\section{Взасмодія компонентів в системі Lu-Ag-Si при 500 C}

${ }^{1}$ Львівський наиіональний університет імені Івана Франка, Львів, Україна, mariya.dzevenko@lnu.edи.иа ${ }^{2}$ Інститут низькотемпературних і структурних досліджень, Польська академія наук, Врочлав 2, Польща, m.daszkiewicz@int.pan.wroc.pl

За результатами рентгенофазового, частково мікроструктурного та ЕДРС аналізів побудовано ізотермічний переріз діаграми стану потрійної системи $\mathrm{Lu}-\mathrm{Ag}-\mathrm{Si}$ при $500{ }^{\circ} \mathrm{C}$ в повному концентраційному інтервалі. Підтверджено існування раніше відомих бінарних сполук з подвійних систем, що оточують потрійну систему $\mathrm{Lu}-\mathrm{Ag}-\mathrm{Si}: \mathrm{LuAg}_{4}, \mathrm{LuAg}_{2}, \mathrm{LuAg} ; \mathrm{LuSi}_{2}, \mathrm{LuSi}, \mathrm{Lu}_{5} \mathrm{Si}_{3}, \mathrm{Lu}_{5} \mathrm{Si}_{4}$. Знайдено нову бінарну сполуку $\mathrm{Lu}_{3} \mathrm{Si}_{5}$ (власний структурний тип). Тверді розчини заміщення утворюються на основі бінарних сполук $\mathrm{LuAg}_{2}$ (структурний тип $\mathrm{MoSi}_{2}$ ) та Lus $\mathrm{Si}_{3}$ (структурний тип $\mathrm{Mn}_{5} \mathrm{Si}_{3}$ ), межі областей гомогенності яких становлять до 20 ат.\% $\mathrm{Si}$ для $\mathrm{LuAg}_{2}$ та до 15 ат.\% $\mathrm{Ag}$ для $\mathrm{Lu}_{5} \mathrm{Si}_{3}$. Інші бінарні сполуки не розчиняють більш ніж 5 ат.\% третього компонента. Існування тернарних сполук у системі Lu-Ag-Si в умовах дослідження не виявлено.

Додатково проведено детальне дослідження кристалічної структури бінарної сполуки LuSi рентгеноструктурним методом монокристалу. Масив експериментальних даних для дослідження отримано на дифрактометрі Oxford X'calibur Atlas (Mo Ka-випромінювання). Сполука LuSi кристалізується в структурі типу TII, просторова група $\mathrm{Cmcm}$, символ Пірсона $o S 8, \mathrm{Z}=4, a=4,1493(3)$, $b=10,2641(7), c=3,7518(2) \AA, R 1=0,0186, w R 2=0,0415$, для 174 незалежних відбить $3 I>2 \sigma(I)$ та 10 змінних.

Ключові слова: потрійна система; ізотермічний переріз; кристалічна структура. 